\section{Documenting Indigenous Identity in the Internet Era: Lessons from the Composition of Narrawong Town Social Profile in Victoria, Australia}

\author{
Annisa Istighfari \\ Master of International Development, RMIT University, Australia \\ e-mail: a.istighfari@gmail.com
}

\begin{abstract}
Together with the process of globalization, the advancement of the Internet has created easy access for researchers to conduct document analysis, which is a low-cost and time-efficient way to gain information about a certain topic. Nevertheless, the resources available on mainstream media mostly come from the Western world, especially the United States. Meanwhile, there are also other sources of knowledge that are inherited within indigenous communities. Reflecting on the experience of composing the community profile of Narrawong, a small town in regional Victoria, Australia, which traditionally belongs to the Gunditjmara people, the author found it challenging to prevent the bias of "modern" information. This bias is due to the limitations in studying the town's indigenous identity using document analysis as a single method. Coming from this experience, the author explored and analyzed alternative ways in which indigenous knowledge can be documented, such as through interactive maps and public use of traditional language. The author also identified barriers to implementing similar efforts, namely the social structure within indigenous communities and different worldviews held by researchers and communities they work with. The author concludes that in doing documentation process, indigenous communities have to be involved in fruitful dialogues so that both the extraction of knowledge and empowerment of indigenous communities can be achieved. This paper is an important resource for those aiming to work on indigenous knowledge documentation.
\end{abstract}

\section{Keywords}

globalization, western bias, indigenous identity, indigenous knowledge

\section{Introduction}

Citation: Istighfari, A.: Documenting Indigenous Identity in the Internet Era: Lessons from the Composition of Narrawong Town Social Profile in Victoria. Australia. In. D. Ekawati, et al (eds.): Proceeding of The American Studies International Conference 2018, Vol. 2, pp. 7-13. UGM Digital Press Social Sciences and Humanities, Yogyakarta (2019).

Published: May, 2019
From June to September 2018, the author was involved in the composition of Narrawong Town Social Profile, which is a community profile of Narrawong, a small regional town in Victoria, Australia. Throughout the process of analyzing documents as the main resources of the composition, the author found that the history of European settlement in the town was very well documented. Information was found not only at a local historical center but also on online libraries. In 
other words, the European side of Narrawong's history had been documented very well by utilizing current technology.

On the other hand, the author had difficulties researching the indigenous side of Narrawong's history. Very little information on the Gunditjmara people, the traditional owners of the land in which Narrawong exists, was present in written form. Reflecting on this experience, the author realized that indigenous knowledge needs to be preserved so that it will not be washed away by the flow of modern information. Documenting indigenous knowledge will not only be beneficial for social researchers but also researchers in other fields who aim to explore the pluralistic approach in their fields of study. However, there are inevitable challenges to the documentation process. In this paper, the author will identify existing efforts to document indigenous knowledge and analyze the barriers to conducting similar efforts.

The Narrawong Town Social Profile is a 40-page document encompassing the history and development of Narrawong since the European settlers first came in the 1860s. The composition of this social profile uses document analysis, a time-efficient and low-cost method to gather data before an actual field study (Bowen, 2009). The profile was composed to prepare for future research on the Indigenous Resource Garden and Sculpture Project at Narrawong Primary School, a project aiming at educating primary school students on indigenous plants, culture, and way of life. This project is partially funded by RMIT University through its Handbury Fellowship program.

In the process of gathering documents to analyze for the profile, the author was supported by the existence of online libraries such as Trove (https://trove.nla.gov.au/). Apart from using the library's collection, which includes articles dating back to the early settlement period, the author also looked for books that discuss Narrawong's history. In general, the main source of the settlement history in this area comes from Major Mitchell's expedition report, Three Expeditions into the Interior of Eastern Australia, which was published in 1839 (Wallace, 2018). More recent history and development of the town are archived at the Portland History House, a historical center in Portland, Narrawong's neighbor town.

Narrawong's history and development cannot be separated from the whaling industry. Whalers were the first Europeans who settled in the area. Inevitably, conflicts happened between these newcomers and the Gunditjmara people. The Convincing Ground, which is arguably the most controversial historical site in the area, is also located in Narrawong. The Ground is believed to be where an indigenous massacre happened in the 1860s. It is called controversial because the exact date of the massacre and the number of Gunditjmara people killed in it remain a debate among historians (Clark, 1995). There are also arguments that refuse the factuality of this massacre.

In order to get a balance of input regarding this incident, the author was looking for information from both the Gunditjmara and European perspectives. However, there was a very limited number of resources that talked about the history of Narrawong and its surrounding areas from the Gunditjmara point of view, let alone ones that explicitly mentioned the Convincing Ground. This experience proves the dominance of Western point of view in the documentation of Australian history, particularly of Narrawong, one of its first settlement areas.

\section{Theoretical Framework}

\subsection{Globalization and the rapid flow of information}

Steger (2009b) defines globalization as the process in which human beings converge into a society where national boundaries become less relevant over time. This process has brought advancement in various aspects of human lives, including information and communication technology (ICT). The invention of the Internet has made it much easier to access information. For researchers, this means the chance to discover journals and books without physically visiting libraries. Discussions with other researchers can also be done remotely through video calls. The availability of open data has also created the space to observe existing data before formulating research questions (Currie-Alder, 2016).

Nevertheless, globalization also has its pitfalls. One of them is how local identities are being left behind in exchange to the neoliberal worldview. This worldview has been spreading through the vast exchange of ideas and information amid the continuous thrive for economic and technological advancement (Steger, 2009a). As summarized by Portnoi (2016), the most prominent debate around globalization is its role in spreading the norms and values of the West to the rest of the world. The challenge that comes with this phenomenon is to preserve local identities in the middle of the homogenizing world.

Khiabany (2003, pp. 147-148) mentions that one of the main causes of this homogenization is the fact that majority of contents on the Internet is produced in the United States (US), where the technology was 
founded in the first place. Khiabany also argues that despite the seemingly bigger chance for ideas from the periphery to emerge through the Internet, major search engines and online news portals are owned by big corporations that are based in the US and other developed countries. The same author mentions how English is used in more than half of the online contents, making its position as the so-called "international language" more prominent as opposed to local languages.

Historically, the dominance of the Western world in the fields of economic development and technological inventions had started in the 1970s. The modernization theory of development explains this phenomenon as the dissemination of "modern characteristics" from the US and its Western counterparts in the effort to avoid the spread of communism (Desai, 2012, p. 54). The pursuit of these so-called modern values has been forcing developing countries to leave their traditional ways of life because they are believed to be the cause of the lack of economic and technological acquisition.

Consequently, the Western media channels have been set as an example for the media development in developing nations. Drawing the examples from Lerner's (1971) and Rogers's (1962) works, Manyozo (2016, p. 4) argues that the support and assistance to improve media institutions in developing nations are based on the idea that the media channels should be the means for "civilization and modernity", implying that indigenous communication systems cannot be utilized together with mainstream channels such as radio and television.

Globalization indeed affects the world's development. However, as suggested by Pieterse (2010), there is no need to completely reject globalization or become overjoyed by it. Instead, globalization should be seen through what he calls "critical globalism", which means seeing globalization not only as of the expansion of international trade but also the interdependence of states and civil societies (p. 48). In order to develop, says Pieterse, countries in the world need something more than "Western ethnocentrism as the implicit culture of developmentalism" (p. 64). This idea started the argument that local culture is an important factor for development. However, a careful approach has to be taken in order not to see local cultures from the Western point of view, thus repeating the same pattern of Western hegemony. The question is then how globalization can be utilized to let local culture reclaims its importance.

\subsection{Indigenous knowledge in the era of globalization}

While there are a variety of ways to define "indigenous knowledge", it is generally understood as the inherited knowledge that comes from a particular place. Grenier (1998, p. 1) defines the term as "the unique, traditional, local knowledge existing within and developed around the specific conditions of women and men indigenous to a particular geographic area". Meanwhile, another definition by Purcell (1998, p. 260) suggests that the term means "the body of historically constituted (emic) knowledge instrumental in the long-term adaptation of human groups to the biophysical environment". While the first definition focuses on the source of indigenous knowledge, that is, the indigenous people themselves; the second emphasizes a close relationship between indigenous knowledge and the way human beings perceive the environment they live in.

As mentioned in the previous section, indigenous knowledge is gradually being acknowledged as a key factor in achieving development. It has even been recognized by the World Bank (WB) as "social capital of the poor" (Gorjestani, 2004, p. 1). The benefits of pairing scientific and indigenous knowledge have also been stated in various resources. Health scientists, for example, have found the advantage of using a pluralistic health approach that combines both modern health science and indigenous ways of healing. One of the arguments supporting this approach is that it offers the means "to address the complexity of the world" (Hertel, 2017). Similarly, Tippins and Mueller (2010) argue that indigenous knowledge opens the door to understand the natural environment.

Many of the indigenous teachings are still relevant to the issues faced in this so-called modern era. The Gunditjmara people, who had lived long before the 1860s, shows a good example of it. Among the small bit of information that has been discovered about them is their aquaculture tradition, which follows what is called "sustainable fisheries" in this era. Using a V-shaped fish trap, the Gunditjmara people were able to capture big fish and let go of small ones. This way, small fish could continue to live and reproduce, ensuring the availability of protein source for the people. This fish trap is only one part of a complex system which is predicted to have existed for 6,700 years, making it one of the first freshwater fish trap systems in the world (Wettenhall, 2010). This example shows that the ways of understanding the environment have been invented long before the birth of modern science.

Unfortunately, the bias of Western values and culture is not only experienced by non-indigenous groups. In fact, challenges have been found in passing indigenous knowledge down to the younger generation of the same community due to their exposure to other sources of knowledge and information. Forutnani, Nowkarizi, Kiani, and Aski's (2018) findings in South Khorasan province, Iran shows that within an 
indigenous community itself there are those who do not understand the value of indigenous knowledge. Meanwhile, Singer, Hoang and Ochiai's (2015) study on Vietnam's Co-tu minority group shows that the increase of influence from electronic media has lessened the chance for younger generations to learn and practice indigenous beliefs.

\section{Findings and Discussions}

\subsection{Existing examples documenting indigenous knowledge documentation}

Knowing that indigenous knowledge is important in various fields, the next step is to find out how to keep the knowledge so that it will not be washed away by the rapid flow of information in the globalization era. There have been existing examples where websites are utilized to educate both indigenous and nonindigenous community members. The Australian Institute of Aboriginal and Torres Strait Islander Studies (AIATSIS), for example, has put in an effort to summarize a large number of indigenous language groups in Australia into one simple map (Australian Institute of Aboriginal and Torres Strait Islander Studies, 2018). Despite its simplicity, the map is an important resource for those who are starting their research on any of these indigenous groups.

Meanwhile, in New Zealand, the Māori language holds an important role as a second language. Apart from being used on road signs and in public places, the language is also used in television broadcasts. Benton (2015, p. 100) argues that the usage of Māori language in platforms visited on a daily basis has increased its "normality" for the general public in the country, albeit not sufficient. Still, the appearances of Māori language in the society where English is the main language have created an opportunity to conserve the Māori culture as a whole.

Conserving traditional practices in the Internet era can also be done by finding alternative ways for young children to spend time apart from using electronic devices. Khasandi-Telewa et al (2012) agree that schools have an important role in this process. Their work in Kenya involves the recording of plays for children using the Luhya traditional songs, which they believe should be used by teachers at schools in order to familiarize students with their local traditions.

\subsection{Barriers to documenting indigenous knowledge}

Keeping indigenous knowledge also has its challenges, apart from the fact that it is passed on through oral forms (Gorjestani, 2004; Sithole, 2007). One of the challenges comes from the social structure of some indigenous communities that determines who holds certain knowledge and whether they are willing to share it. "Sharing", in this case, does not only mean opening up to researchers or the general public but also other members within the same community. In some communities, women have more knowledge than men in terms of agricultural processes (Sithole, 2007) while in other contexts shamans would like to keep their social status as the only ones that can cure ill people (Chisenga, 2002). These examples show that in some cases, indigenous knowledge is exclusively held by particular groups within a community.

It is also important to take note of the difficulty to understand indigenous practices that have a strong relationship with religious or spiritual values. Some indigenous communities believe that knowledge belongs to God and sharing it to those in need is part of their faith (Forutnani et al., 2018), while some others practice rituals that are often regarded as "irrational" when seen from a scientific perspective (Chisenga, 2002, p. 18). A thorough understanding of the whole worldview is crucial before extracting indigenous knowledge to be documented. Unfortunately, this process may take a lot of time and effort.

The documentation of indigenous knowledge also brings in the issue of legal ownership, both for physical and intellectual properties. Fernandez (1994), for example, is critically aware that some agricultural practices patented under the name of multicultural corporations in the Philippines are based on indigenous knowledge (p. 235). These companies would modify indigenous agricultural practices and claim ownership of the so-called innovation. While legal requirements may be met, ethical questions should be raised on the distribution of benefits between the companies and the indigenous communities. After all, the indigenous communities have owned and utilized the agricultural systems long before they were discovered and modified by the companies.

Concerns around ownership are also related to the power relations between the indigenous and nonindigenous groups. If those who do not belong to the indigenous group that holds certain knowledge are able to learn it, what does it mean to the indigenous community? This issue is especially important when the indigenous community only has small contributions in the decision-making process. An example of this 
concern was found in New Zealand in 1990, when Māori-language science curriculum was formulated with very little involvement of the Māori community, creating less space for them to put in their "aspirations and cultural priorities" (Kidman et al., 2011, pp. 207-208).

\subsection{Discussion: indigenous knowledge documentation and the importance of dialogue}

The examples provided in this paper come from Australia, New Zealand, and Kenya. The resemblance of the three examples lies in the involvement of the indigenous groups in the process of knowledge extraction. Overcoming the dominance of Western knowledge together with indigenous community members is crucial in order to achieve both the documentation of knowledge itself and the empowerment of the community. In other words, the documentation of indigenous knowledge has to be done in a way that does not patronize indigenous community, but rather give them space to emerge.

Nevertheless, indigenous knowledge should be regarded as more than a tangible asset. More than anything, it is a symbol of identity and resistance toward the Western hegemony. The acceptance of indigenous knowledge means the realization that following traditional practices do not mean being left behind amid the globalizing world. It is also evidence that the "traditional" and "modern" worlds can exist side by side, hence showing that the abolishment of local values is not necessary for the process of development.

This argument also applies for the Indigenous Resource Garden and Sculpture Project at Narrawong Primary School, the umbrella project wherein the composition of Narrawong Town Social Profile takes place. The process of designing and building a school garden with native plants and the infusion of Gunditjmara art forms should be seen as a way to achieve stronger relationships among indigenous and non-indigenous communities in the area. Most importantly, it is the way to teach primary school students that modern science and indigenous values are both crucial in shaping their future.

Dialogues with indigenous communities are necessary to overcome the challenges that come with the effort of keeping traditional values in the Internet era. Based on the points mentioned in this paper, challenges mainly come from two sources: the social structure within indigenous groups and the ways they perceive knowledge, spirituality, and ownership. Those who are willing to learn indigenous knowledge must be able to understand this difference in worldview in order for fruitful conversations to take place.

\section{Conclusions}

The difficulty that the author was facing in getting the indigenous perspective on the history of Narrawong, Victoria, Australia has also been faced in other parts of the world. Indeed, Western dominance in knowledge documentation is the result of a long history of Eurocentrism and the process of modernization in the world, particularly in developing nations. Globalization, which brings the ease of communication and cultural diffusion from one place to another, can be seen as the perpetrator of this hegemony. However, the advancement of ICT can also be utilized to conserve indigenous knowledge. Dialogues with indigenous communities have to take place in order to face obstacles of gaining and documenting the knowledge, considering different worldviews possessed by researchers and communities they work with. At the end of the day, the documentation of indigenous knowledge should not only benefit those outside indigenous groups but also empower the indigenous communities.

Due to word limits, this paper has not been able to delve deeper into the strategies of involving indigenous groups in the decision-making process for indigenous knowledge documentation. Further research should also be done to examine the power relations within indigenous groups and how to work effectively with them without overlooking the importance of particular roles in indigenous social structures. 


\section{Acknowledgment}

The author is an awardee of the Indonesia Endowment for Education (LPDP) Scholarship from the Ministry of Finance, Republic of Indonesia.

\section{References}

1. Australian Institute of Aboriginal and Torres Strait Islander Studies. (2018). AIATSIS map of Indigenous Australia. Retrieved from https://aiatsis.gov.au/explore/articles/aiatsis-mapindigenous-australia

2. Benton, R.A. (2015). Perfecting the partnership: Revitalising the Māori language in New Zealand education and society 1987-2014. Language, Culture and Curriculum, Vol (2), pp. 99-112. DOI: 10.1080/07908318.2015.1025001

3. Bowen, G.A. (2009). Document analysis as a qualitative research method. Qualitative Research Journal, 9(2), pp. 27-40. https://doi.org/10.3316/QRJ0902027

4. Chisenga, J. (2002). Indigenous knowledge: Africa's opportunity to contribute to global information content. South African Journal of Libraries and Information Science, 68(1), 16-20.

5. Clark, I.D. (1995). Scars in the landscape: a register of massacre sites in western Victoria, 1803-1859 (Report series, Australian Institute of Aboriginal and Torres Strait Islander Studies). Retrieved from http://nationalunitygovernment.org/pdf/2014/IanDClark-Scars_in_the_landscape.pdf.pdf

6. Currie-Alder, B. (2016). The state of development studies: origins, evolution, and prospects. Canadian Journal of Development Studies, 37(1), 5-26. DOI: 10.1080/02255189.2016.1135788

7. Desai, R. (2012). Theories of development. In P. A. Haslam, J. Schafer, \& P. Beaudet (Eds.), Introduction to international development: Approaches, actors, and issues (pp.45-67). Oxford University Press.

8. Fernandez, P. G. (1994). Indigenous seed practices for sustainable agriculture. Indigenous Knowledge and Development Monitor, 2(2), 9-12.

9. Forutnani, S., Nowkarizi, M., Kiani, M.R., \& Aski, H.R.M. (2018). The role of rural libraries in preserving the indigenous knowledge of rural residents: The case of South Khorasan Province. World Journal of Science, Technology and Sustainable Development, Vol 15(3), 245-256. https://doi.org/10.1108/WJSTSD-12-2017-0044

10. Gorjestani, N. (2004). Indigenous knowledge for development: Opportunities and challenges (Indigenous Knowledge for Development Program, The World Bank). Retrieved from http://documents.worldbank.org/curated/en/574381468765625385/pdf/multi0page.pdf

11. Grenier, L. (1998). Working with indigenous knowledge: A guide for researchers. Canada: International Development Research Centre.

12. Hertel, A. L. (2017). Applying Indigenous Knowledge to Innovations in Social Work Education. Research on Social Work Practice, 27(2), 175-177.

13. Khasandi-Telewa, V., Liguyani, R. I., \& Wandera-Simwa, S. (2012). Appropriating globalization to revitalize indigenous knowledge and identity through Luhya children's play songs. Journal of Pan African Studies, 5(6), 76-91.

14. Khiabany, G. (2003). Globalization and the Internet: Myths and realities. Trends In Communication, 11(2), 137-153.

15. Kidman, J., Abrams, E., \& McRae, H. (2011). Imaginary subjects: School science, indigenous students, and knowledge-power relations. British Journal of Sociology of Education, 32(2), 203220. doi: 10.1080/01425692.2011.547306

16. Manyozo, L. (2016). The Governance and Sustainable Livelihoods Strands in Media Development. DW Akademie. Retrieved from https://www.dw.com/downloads/35959515/mediadevmanyozoeditiondwakademie2016.pdf

17. Pieterse, J.N. (2010). Development Theory: Deconstructions/reconstructions (2nd ed.). Los Angeles; London: SAGE.

18. Portnoi, L. (2016). Policy Borrowing and Reform in Education: Globalized Processes and Local Contexts. New York: Palgrave Macmillan US.

19. Purcell, T. W. (1998). Indigenous knowledge and applied anthropology: Questions of definition and direction. Human Organization, 57(3), 258-272. https://search-proquestcom.ezproxy.lib.rmit.edu.au/docview/201155308?accountid=13552 
20. Singer, J., Hoang, H., \& Ochiai, C. (2015). Post-displacement community resilience: Considering the contribution of indigenous skills and cultural capital among ethnic minority Vietnamese. Asia Pacific Viewpoint, 56(2), 208-222.

21. Sithole, J. (2007). The challenges faced by African libraries and information centres in documenting and preserving indigenous knowledge. IFLA journal, 33(2), 117-123.

22. Steger, M. (2009a). Globalisation and social imaginaries: The changing ideological landscape of the twenty-first century. Journal of Critical Globalisation Studies, 1(1), 9-30. http://researchbank.rmit.edu.au/view/rmit:3810

23. Steger, M. (2009b). Globalization: a very short introduction. https://ebookcentral.proquest.com

24. Tippins D.J., \& Mueller, M.P. (2010) .The need for confluence: Why a "river" runs through it. In D. Tippins, M. Mueller, M. van Eijck, \& J. Adams (Eds.), Cultural studies and environmentalism (Cultural Studies of Science Education, vol. 3, pp. 1-4). Dordrecht, NL: Springer.

25. Wallace, B. (2018). Place names of Portland and the Glenelg Shire of Victoria, Portland: VIC: E. Davis \& Sons Pty Ltd.

26. Wettenhall, G. (2010). The people of Budj Bim: Engineers of aquaculture, builders of stone house settlements and warriors defending country. Heywood: VIC: Em Press Publishing. 